\title{
Some broad-scale effects of recent and future climate change among migratory birds in Beringia
}

\author{
Kevin Winker $^{1, *}$ and Daniel D. Gibson ${ }^{1}$
}

\begin{abstract}
Birds from all seven continents come to Beringia to breed in the northern summer. For birds breeding there, Beringia's position at the head of the Pacific Ocean requires substantial longitudinal (east to west and west to east) movements coming and going. These movements are most apparent to us in continental "crossover" species, Asian taxa breeding in North America and North American birds breeding in Asia. Those individuals reaching range limits in Beringia commonly travel long distances to take advantage of short summers, and many of their range limits are likely caused by time constraints: travel time plus the time required to successfully reproduce and (for most) to molt must fit into the finite constraints of the length of the summer. These constraints become most apparent when a breeding range limit is longitudinally distant from the nearest wintering area, and the most visible examples involve species whose ranges stop before the limit of apparently appropriate habitat. It is these species whose ranges we expect to change most rapidly when even small increases in the time available at high latitudes (i.e., a longer growing season) give them more time to travel farther east or west at these latitudes.
\end{abstract}

Keywords: Asia, Beringia, continental colonization, migration, North America, range shifts, time limitation

$\mathrm{P}$ rojections of the effects of global warming in Alaska and northwestern Canada suggest comparatively high rates of climate change and a lengthened growing season (Tingley and Huybers 2013, Chapin et al. 2014). Even subtle changes will affect the biota of this region. Birds have long served as indicators of environmental health (e.g., canaries in coal mines, Silent Spring, Spotted Owl), and, because of their mobility, many bird species are likely to be among the first organisms to show changes in distribution associated with current climate change. Birds' visibility makes them relatively easy to detect, and on the basis of simple presence-absence, mapping their ranges is comparatively easy. Furthermore, unlike most of North America, Alaska and northwestern Canada represent vast, natural ecosystems with little direct anthropogenic modification. Thus any range shifts observed are not likely to be caused by direct anthropogenic modifications of habitat.

For many bird species, structural considerations of habitat are important. For example, a requisite tree nester cannot nest where there are no trees. Populations of other species probably experience range limitation due not to structure but to the amount of time available to successfully reproduce

and molt near the northern limits of the species' range. Such species, which are time-limited only in these edge populations, should show more rapid changes in distribution. Resource-limited species should show slower change, because there will be some lag time in, for example, the growth of forest where it does not presently occur. This scenario is perhaps simplistic, but in sum we expect the ranges of time-limited species to shift relatively rapidly when requisite substrate exists in an area (especially a contiguous area) not previously occupied (Figure 1). Note that this hypothesis considers only populations at the northern edge of a range, those most likely to be time limited, and it makes no predictions about changes elsewhere

\begin{tabular}{lcc} 
& \multicolumn{2}{c}{ Limitation } \\
\cline { 2 - 3 } Structure & Time & Resources \\
\hline Nonlimiting & I & II \\
Limiting & III & IV \\
\hline
\end{tabular}

Figure 1. Partitioning the limitations that species experience at the edges of their ranges in northwestern North America and northeastern Asia. Category I species will likely show most rapid change with increased growing season and are the focus of this paper.

Full citation: Winker, K., and Gibson, D. D. 2018. Some broad-scale effects of recent and future climate change among migratory birds in Beringia, in Trends and traditions: Avifaunal change in western North America (W. D. Shuford, R. E. Gill Jr., and C. M. Handel, eds.), pp. 432-440. Studies of Western Birds 3. Western Field Ornithologists, Camarillo, CA; doi 10.21199/SWB3.23.

${ }^{1}$ University of Alaska Museum, 907 Yukon Drive, Fairbanks, Alaska 99775; *corresponding author: kevin.winker@alaska.edu 
in the range (where we expect time limitation to be a less important factor).

Another consideration that emphasizes the importance of continued monitoring of range shifts rather than focusing on abundance in assessing the effects of climate change is that abundance changes may be due to many factors, including phenomena acting on species' winter ranges. Range limits, on the other hand, are largely defined climatologically and physically (though in some species increased abundance can cause range expansion); range shifts generally reflect changes in the physical constraints (and the ecological conditions they produce) at the geographic limits of a species' tolerance. In many documented cases, these changes have been caused by direct anthropogenic changes opening up new habitats for a species. In the vast untouched reaches of northwestern North America, however, such anthropogenic alterations play an insignificant role.

\section{RANGE EXPANSIONS}

The ranges of many North American landbirds project toward the northwest, probably reflecting a prehistoric advance in the interior of the continent as environments moderated after glaciation (Figure 2). It is among these species that we might look first for continued range expansion as conditions become more favorable beyond the present northwestern edges of their ranges. Many North American species will likely spread northward, but expansion in this direction is not as easy to document as that to the west, particularly when these high latitudes have relatively few human observers.

Note that we are considering only species likely to be affected by time limitation in Beringia. This

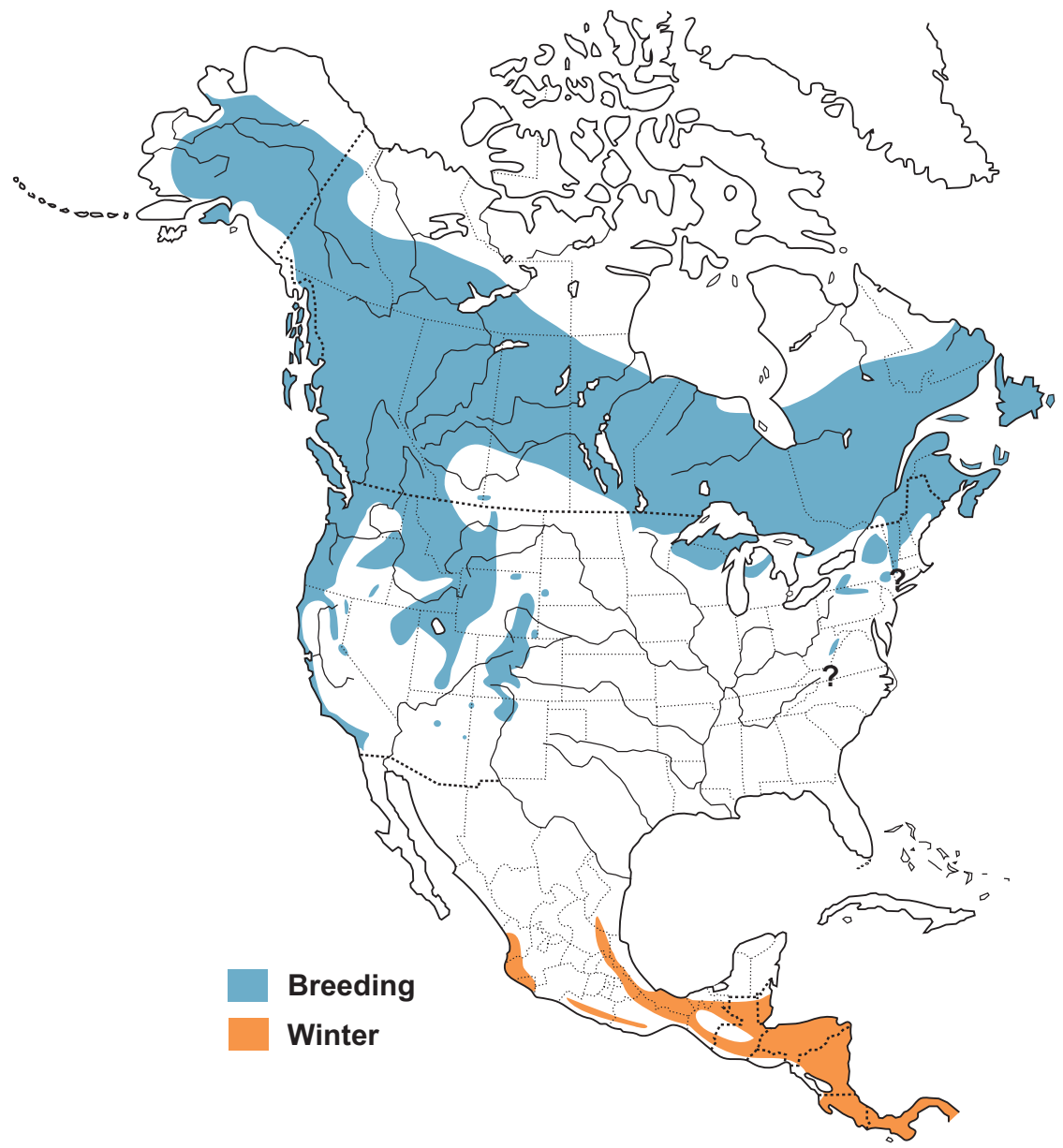

Figure 2. North American range of Swainson's Thrush (Catharus ustulatus), an example of how many landbird species' breeding ranges project northwest, after occupation of regions that were covered by ice during the last glacial maximum. From Birds of North America online (birdsna.org), used by permission. 
region has been rather loosely defined, but for our purposes it is roughly the area between the Lena River in Siberia and the Mackenzie River in Canada south to about the tip of the Kamchatka Peninsula (West 1998; Figure 3). Other environmental and ecological factors are important, such as habitat and prey availability and probably competitive exclusion in new avian assemblages. Thus we do not expect all species with northwestward range projections to spread, or for those that do to respond equivalently in distance. Indeed, numerous studies have shown that individual species respond in complex, heterogeneous ways to the multiple effects of global warming such as changes in temperature and precipitation (e.g., Angert et al. 2011, Tingley et al. 2012). Predictive models are incorporating an increasing number of potentially important factors (e.g., Huntley et al. 2008, Angert et al. 2011, Barbet-Massin et al. 2012). Because factors such as habitat and prey availability, precipitation, and competitive exclusion might affect a species' longitudinal distribution in Beringia, they may be difficult or impossible to tease out from time effects alone. Nevertheless, time constraints have thus far not been a factor in these models.

While numerous studies have documented avian range shifts associated with climate change-primarily poleward and in elevation(e.g., Zuckerberg et al. 2009, Auer and King 2014, Virkkala and Lehikoinen 2014, Mizel et al. 2016), wider considerations of non-poleward shifts are only beginning to be addressed. For example, Gillings et al. (2015) found that range shifts among British birds have been multidirectional, with extensions to the northeast and northwest being most pronounced.

Populations of obligate migrants near the northern edges of their ranges often occupy their breeding ground for notably short periods. For example, Benson and Winker (2001), examining the median dates of spring and autumn passage of adult passerines at Fairbanks, Alaska, inferred occupancy of the breeding range as short as 48 days in the Alder Flycatcher (Empidonax alnorum), a species that molts after autumn migration, and 84-86 days in the Yellow Warbler, (Setophaga petechia), Northern Waterthrush (Parkesia noveboracensis), and Hammond's Flycatcher (Empidonax hammondii), species molting prior to autumn migration. Given that the vast majority of the birds recorded in this study were still in migration, these median dates may be considered to indicate the maximum average numbers of days spent on breeding grounds for populations to the north and west of Fairbanks. This location had an average frost-free period of 105 days and, on the short side, a minimum possible period of just 51 days (at the time of the study in the 1990s). These are thermal factors affecting prey availability (especially for insectivores) and almost certainly representing strong selective forces on the timing of movements and breeding (e.g., nearly all species examined timed their movements to coincide within the long-term average frost-free period).

The main challenge that such time constraints place on these populations is on reproduction: compressing the time to obtain a territory, build a nest, lay eggs, incubate, feed young to independence, and (for most species) molt before having to migrate to wintering grounds. We can see the effects of these time constraints in several ways. One is that double brooding (successfully raising more than one clutch of offspring) is rare at high latitudes (Hussell et al. 2014). Another is a negative effect on clutch size (Rowe et al. 1994), and yet another is in the degree to which high-latitude populations overlap the energetically demanding life stages of reproduction, molt, and migration, long considered to be so energy intensive as to be separated temporally among most birds (e.g., Payne 1972, Cannell et al. 1983, Vega-Rivera et al. 1998). It is no accident that the highest levels of overlap between these energetically costly stages are being found among high-latitude populations, where evidently there is simply not enough time to spread them out as at lower latitudes (Rimmer 1988, Flockhart 2010, Benson and Winker 2015).

For example, among 17 species of passerine migrants at Fairbanks, Alaska, Benson and Winker (2015) found a negative correlation between the length of occupancy of the breeding ground (defined by the difference between median spring and autumn dates of passage) and the amount of overlap of molt and migration. In addition, they found high levels of overlap of molt with fat accumulation. Both findings are concordant with the hypothesis that time constraints promote overlap of these energetically demanding undertakings.

Here, our methods for considering time limitation likely to be affecting a migratory species' range edge included examination of migratory species' range edges in Beringia, habitat, and whether the range of likely ecological replacement species (e.g., a closely related congener) might prove a more limiting factor (through competitive exclusion). As noted above, other factors can also affect ranges; we focus on where time constraints are most likely to be active. Sources included the Birds of North America Online (Rodewald 2015), 


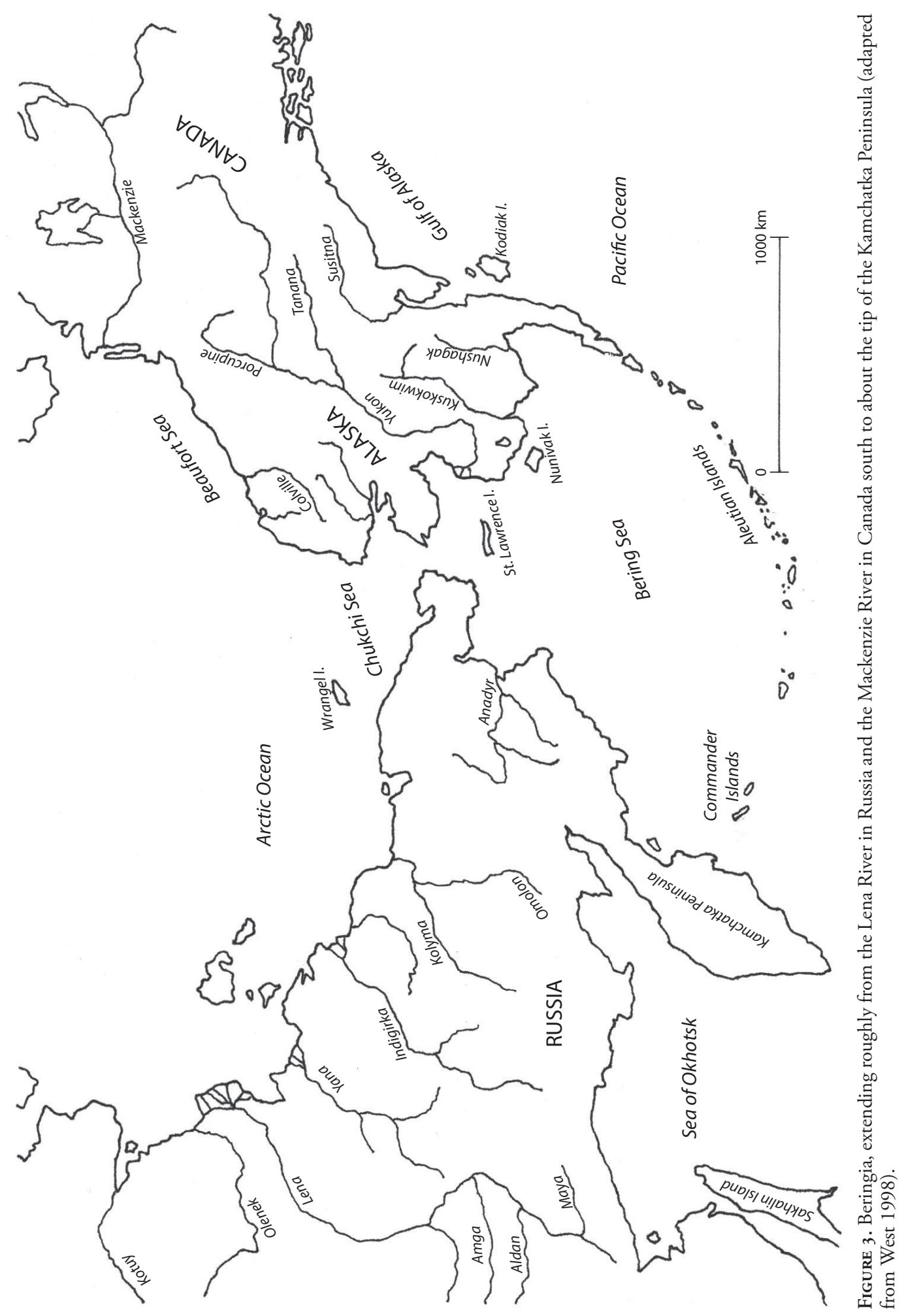


National Geographic (2002), del Hoyo et al. (1992-2011), and Brazil (2009). Taxonomy follows AOU (1957, 1998), Browning (1988), and Gibson and Withrow (2015).

There are many migratory North American species whose range is likely to spread in eastern Beringia relatively quickly (over the course of decades, rather than centuries) in response to climate change (Table 1). There are also many Asian species likely to undergo relatively rapid range expansions in western Beringia in response to a longer growing season at high latitudes (Table 2). And, finally, there is a smaller subset of migratory species from both continents that have already colonized (or nearly so) the opposite continent in which we can expect range expansions farther east (for Asian species) or west (for North American species) as warming continues and breeding seasons at these latitudes lengthen (Table 3). We observe again that multiple factors affect range edges, and that time constraints alone are not likely to be able to be teased out as acting alone in relation to other factors. However, it is among these species that we most expect time limitation to play a role in Beringian range limits.

\section{CONTIGUITY: STEPPING-STONE VERSUS CONTINUOUS-FronT MODELS}

Range shifts across a continent with contiguous habitat will probably proceed on a continuous front, moving gradually. This suggestion is supported by the varying positions of the northwestern (and northeastern in Asia) fronts of species' ranges currently: no clear thresholds or transitions are evident. Among islands and archipelagoes, however, an island must be able to sustain a population before a species can successfully colonize. Thus among islands and archipelagoes we can expect more stutter, or greater variance, as these relatively small patches of range become suddenly available to a species (due also to habitats being noncontiguous and the distances between them; MacArthur and Wilson 1967). Conceptually, landbird species colonizing North America from Asia may follow a similar pattern, given the important water crossing of the Bering and Chukchi seas that some species appear to make easily while others do not (yet). For a number of these, ecological replacements already on the continent being potentially colonized may exclude them through competition (particularly members of the same genus or of the same species, in cases of polytypic species with different subspecies on opposite sides of the Bering Sea). In such cases ecological rather than climatological factors will play a more important role in determining range edges. We have excluded such taxa from our tables (e.g., the tattlers, Tringa brevipes and $T$. incana). Alaska, with a massive interior and a vast number of islands, is a superb natural laboratory in which these continuing and likely accelerating natural experiments might be observed.

There is a strong latitudinal component to habitat contiguity, and this has had important biogeographic consequences. The similarities of the arctic and Beringian avifaunas of Asia and North America increase with latitude (Mayr 1946, Kessel 1963, Stegmann 1963). Thus, for example, we expect less habitat contiguity and a higher threshold for intercontinental colonization and range expansion for forest-associated species than for nonforest species.

\section{SOME CONSEQUENCES OF RANGE SHIFT}

Most natural intercontinental colonists (e.g., Table 3) have not had any recognized negative effects on the avifauna of the continent being colonized. However, if Asian cuckoos, obligate nest parasites, colonize North America (Table 2), we're likely to see severe negative consequences among North American songbirds, particularly among the many naïve populations in much of northwestern North America.

The combination of two migration systems in Alaska makes it likely that in this region birds cause regular intercontinental exchange of pathogens (e.g., Winker et al. 2007, Pearce et al. 2011, Runstadler et al. 2013, Lee et al. 2015). The same is true of parasites. These exchanges have not been well studied, so we do not yet know the frequency of such occurrences. However, mixing of birds from these two migration systems is likely to increase with warming because longer summers at high latitudes will increase overlaps in both ranges and the time of occupancy of high latitudes. New combinations of species will also arise. Increased mixing and new combinations of vector species will provide what will essentially be dynamic new host communities, a cauldron of new opportunities for colonization of hosts, viral reassortment, and selection. Lee et al. (2015) indicated that the highly pathogenic avian influenza outbreak of 2014-15 in North America was due to wild birds introducing the virus through this intercontinental contact zone. This suggests that the consequences of the mixing of vectors, diseases, and parasites in this region could be profound for birds and humans. 
TABLE 1. Migratory North American birds for which we might expect north and westward range expansions within or into Beringia. This list excludes North American species already breeding in Asia, but includes some that might colonize Asia. Subspecies included where relevant.

\begin{tabular}{|c|c|c|c|}
\hline Cackling Goose & Branta hutchinsii & Philadelphia Vireo & Vireo philadelphicus \\
\hline Blue-winged Teal & Anas discors & Red-eyed Vireo & Vireo olivaceus olivaceus \\
\hline Canvasback & Aythya valisineria & Purple Martin & Progne subis subis \\
\hline Redhead & Aythya americana & Tree Swallow & Tachycineta bicolor \\
\hline Ring-necked Duck & Aythya collaris & Violet-green Swallow & Tachycineta thalassina \\
\hline Lesser Scaup & Aythya affinis & & thalassina \\
\hline Hooded Merganser & Lophodytes cucullatus & Northern Rough-winged & Stelgidopteryx serripennis \\
\hline Ruddy Duck & Oxyura jamaicensis rubida & Swallow & serripennis \\
\hline Pied-billed Grebe & Podilymbus podiceps podiceps & Cliff Swallow & Petrochelidon pyrrhonota \\
\hline Horned Grebe & Podiceps auritus cornutus & & pyrrhonota \\
\hline American Bittern & Botaurus lentiginosus & Barn Swallow & Hirundo rustica erythrogaster \\
\hline $\begin{array}{l}\text { Black-crowned } \\
\text { Night-Heron }\end{array}$ & Nycticorax nycticorax hoactli & $\begin{array}{l}\text { House Wren } \\
\text { Marsh Wren }\end{array}$ & $\begin{array}{l}\text { Troglodytes aedon parkmanii } \\
\text { Cistothorus palustris plesius }\end{array}$ \\
\hline Northern Harrier & Circus cyaneus hudsonius & Golden-crowned Kinglet & Regulus satrapa amoenus \\
\hline Sharp-shinned Hawk & Accipiter striatus velox & Ruby-crowned Kinglet & Regulus calendula calendula \\
\hline Broad-winged Hawk & Buteo platypterus platypterus & Mountain Bluebird & Sialia currucoides \\
\hline Swainson's Hawk & Buteo swainsoni & Townsend's Solitaire & Myadestes townsendi townsend \\
\hline Red-tailed Hawk & Buteo jamaicensis harlani & Veery & Catharus fuscescens salicicola \\
\hline Yellow Rail & Coturnicops noveboracensis & Swainson's Thrush & Catharus ustulatus incanus \\
\hline Sora & Porzana carolina & Hermit Thrush & Catharus guttatus euborius \\
\hline American Coot & Fulica americana americana & American Robin & Turdus migratorius migratorius \\
\hline Killdeer & Charadrius vociferus vociferus & Varied Thrush & Ixoreus naevius meruloides \\
\hline Short-billed Dowitcher & Limnodromus griseus caurinus & Gray Catbird & Dumetella carolinensis \\
\hline Upland Sandpiper & Bartramia longicauda & European Starling & Sturnus vulgaris vulgaris \\
\hline Wilson's Phalarope & Phalaropus tricolor & Cedar Waxwing & Bombycilla cedrorum \\
\hline Franklin’s Gull & Leucophaeus pipixcan & Smith's Longspur & Calcarius pictus \\
\hline California Gull & Larus californicus albertaensis & Ovenbird & Seiurus aurocapilla aurocapilla \\
\hline Caspian Tern & Hydroprogne caspia & Northern Waterthrush & Parkesia noveboracensis \\
\hline Black Tern & Chlidonias niger surinamensis & Black-and-white Warbler & Mniotilta varia \\
\hline Common Tern & Sterna hirundo hirundo & Tennessee Warbler & Oreothlypis peregrina \\
\hline Black-billed Cuckoo & Coccyzus erythropthalmus & Orange-crowned Warbler & Oreothlypis celata celata \\
\hline Northern Saw-whet Owl & Aegolius acadicus acadicus & Connecticut Warbler & Oporornis agilis \\
\hline Common Nighthawk & Chordeiles minor minor & MacGillivray's Warbler & Geothlypis tolmiei tolmiei \\
\hline Black Swift & Cypseloides niger borealis & Mourning Warbler & Geothlypis philadelphia \\
\hline Ruby-throated & Archilochus colubris & Common Yellowthroat & Geothlypis trichas campicola \\
\hline Hummingbird & & American Redstart & Setophaga ruticilla \\
\hline Anna's Hummingbird & Calypte anna & Cape May Warbler & Setophaga tigrina \\
\hline Rufous Hummingbird & Selasphorus rufus & Magnolia Warbler & Setophaga magnolia \\
\hline Belted Kingfisher & Megaceryle alcyon & Bay-breasted Warbler & Setophaga castanea \\
\hline Yellow-bellied Sapsucker & Sphyrapicus varius & Yellow Warbler & Setophaga petechia banksi \\
\hline American Kestrel & Falco sparverius sparverius & Blackpoll Warbler & Setophaga striata \\
\hline Olive-sided Flycatcher & Contopus cooperi cooperi & Palm Warbler & Setophaga palmarum \\
\hline Western Wood-Pewee & Contopus sordidulus veliei & & palmarum \\
\hline Yellow-bellied Flycatcher & Empidonax flaviventris & Yellow-rumped Warbler & Setophaga coronata hooveri \\
\hline Alder Flycatcher & Empidonax alnorum & Townsend's Warbler & Setophaga townsendi \\
\hline Least Flycatcher & Empidonax minimus & Black-throated Green & Setophaga virens virens \\
\hline Hammond's Flycatcher & Empidonax hammondii & Warbler & \\
\hline Dusky Flycatcher & Empidonax oberholseri & Canada Warbler & Cardellina canadensis \\
\hline Eastern Phoebe & Sayornis phoebe & Wilson's Warbler & Cardellina pusilla pileolata \\
\hline Great Crested Flycatcher & Myiarchus crinitus & American Tree Sparrow & Spizelloides arborea ochracea \\
\hline Eastern Kingbird & Tyrannus tyrannus & Chipping Sparrow & Spizella passerina arizonae \\
\hline Cassin’s Vireo & Vireo cassinii cassinii & Clay-colored Sparrow & Spizella pallida \\
\hline Blue-headed Vireo & Vireo solitarius solitarius & Brewer’s Sparrow & Spizella breweri taverneri \\
\hline Warbling Vireo & Vireo gilvus swainsoni & Vesper Sparrow & Pooecetes gramineus confinis \\
\hline
\end{tabular}


TABLE 1. (Continued.)

\begin{tabular}{|c|c|}
\hline Savannah Sparrow & $\begin{array}{l}\text { Passerculus sandwichensis } \\
\text { sandwichensis }\end{array}$ \\
\hline LeConte's Sparrow & Ammodramus leconteii \\
\hline $\begin{array}{l}\text { Nelson's Sharp-tailed } \\
\text { Sparrow }\end{array}$ & Ammodramus nelsoni \\
\hline Fox Sparrow & $\begin{array}{c}\text { Passerella iliaca zaboria } \\
\text { and unalaschcensis }\end{array}$ \\
\hline Song Sparrow & Melospiza melodia merrilli \\
\hline Lincoln's Sparrow & Melospiza lincolnii lincolnii \\
\hline Swamp Sparrow & Melospiza georgiana ericrypta \\
\hline Harris's Sparrow & Zonotrichia querula \\
\hline White-throated Sparrow & Zonotrichia albicollis \\
\hline White-crowned Sparrow & $\begin{array}{l}\text { Zonotrichia leucophrys } \\
\text { gambelii and } \\
\text { Z. l. pugetensis }\end{array}$ \\
\hline Golden-crowned Sparrow & Zonotrichia atricapilla \\
\hline Dark-eyed Junco & Junco hyemalis hyemalis \\
\hline Western Tanager & Piranga ludoviciana \\
\hline Rose-breasted Grosbeak & Pheucticus ludovicianus \\
\hline Red-winged Blackbird & Agelaius phoeniceus arctolegus \\
\hline Yellow-headed Blackbird & Xanthocephalus xanthocephalus \\
\hline Rusty Blackbird & Euphagus carolinus carolinus \\
\hline Brewer’s Blackbird & Euphagus cyanocephalus \\
\hline Brown-headed Cowbird & Molothrus ater artemisiae \\
\hline
\end{tabular}

\section{Examples}

There is some evidence for current range expansions among time-limited migrants in Beringia. Whether these shifts are due in whole or in part to relaxation of time constraints is not known, but North American examples include Wilson's Phalarope (Phalaropus tricolor; Erwin et al. 2004), Caspian Tern (Hydroprogne caspia; Gibson and Withrow 2015 and citations therein), Common Nighthawk (Chordeiles minor minor; Sinclair et al. 2003), Yellow-bellied Flycatcher (Empidonax flaviventris; Benson et al. 2000, Martin et al. 2006), Cassin's Vireo (Vireo cassinii cassinii; DeCicco and Hajdukovich 2008), Tennessee Warbler (Oreothlypis peregrina; Gibson and Withrow 2015), Cape May Warbler (Setophaga tigrina; Tobish 2014), and White-crowned Sparrow (Zonotrichia leucophrys pugetensis; Gibson and Withrow 2015). Asian examples include the Tree Swallow (Tachycineta bicolor), Cliff Swallow (Petrochelidon pyrrhonota), American Robin (Turdus migratorius), Fox Sparrow (Passerella iliaca unalaschcensis), Savannah Sparrow (Passerculus sandwichensis), Dark-eyed Junco (Junco hyemalis), and American Tree Sparrow (Spizella arborea; Arkhipov and Ławicki 2016).

In summary, we expect climatic warming in Beringia to enable some species of migratory birds,

TABLE 2. Migratory Asian birds for which we may see eastward range expansions within or into western Beringia and, for many, possible colonization into North America. Subspecies included where relevant.

Baikal Teal

Tufted Duck

Smew

Eurasian Dotterel

Terek Sandpiper

Spotted Redshank

Common Greenshank

Black-tailed Godwit

Great Knot

Sharp-tailed Sandpiper

Temminck's Stint

Long-toed Stint

Spoon-billed Sandpiper

Red-necked Stint

Little Stint

Jack Snipe

Common Snipe

Pin-tailed Snipe

Black-headed Gull

Slaty-backed Gull

Common Cuckoo

Oriental Cuckoo

Fork-tailed Swift

Eurasian Kestrel

Northern Hobby

Brown Shrike

Common House-Martin

Willow Warbler

Common Chiffchaff

Dusky Warbler

Pallas's Leaf Warbler

Yellow-browed Warbler

Siberian Rubythroat

Red-flanked Bluetail

Taiga Flycatcher

Stonechat

Dusky Thrush

Redwing

Siberian Accentor

Gray Wagtail

Pechora Pipit

Eurasian Bullfinch

Common Rosefinch

Pallas's Rosefinch

Hawfinch

Little Bunting

Rustic Bunting

Yellow-breasted Bunting

Pallas's Bunting
Anas formosa

Aythya fuligula

Mergellus albellus

Charadrius morinellus

Xenus cinereus

Tringa erythropus

Tringa nebularia

Limosa limosa melanuroides

Calidris tenuirostris

Calidris acuminata

Calidris temminckii

Calidris subminuta

Calidris pygmea

Calidris ruficollis

Calidris minuta

Lymnocryptes minimus

Gallinago gallinago gallinago

Gallinago stenura japonica

Chroicocephalus ridibundus

Larus schistisagus

Cuculus canorus canorus

Cuculus optatus

Apus pacificus pacificus

Falco tinnunculus interstinctus

Falco subbuteo subbuteo

Lanius cristatus cristatus

Delichon urbicum lagopodum

Phylloscopus trochilus yakutensis

Phylloscopus collybita tristis

Phylloscopus fuscatus fuscatus

Phylloscopus proregulus

Phylloscopus inornatus

Luscinia calliope

Tarsiger cyanurus

Ficedula albicilla

Saxicola torquatus stejnegeri

Turdus naumanni eunomus

Turdus iliacus iliacus

Prunella montanella badia

Motacilla cinerea robusta

Anthus gustavi gustavi

Pyrrhula pyrrhula cassinii

Carpodacus erythrinus grebnitskii

Carpodacus roseus roseus

Coccothraustes coccothraustes japonicus

Emberiza pusilla

Emberiza rustica latifascia

Emberiza aureola ornata

Emberiza pallasi polaris 
TABle 3. Birds from North America whose breeding ranges in Asia may spread farther west, and Asian birds whose breeding ranges in North America may spread farther east. Subspecies included where relevant.

\section{North American birds in Asia}

\section{Snow Goose}

Sandhill Crane

Baird's Sandpiper

Buff-breasted Sandpiper

Pectoral Sandpiper

Semipalmated Sandpiper

Western Sandpiper

Long-billed Dowitcher

Gray-cheeked Thrush

Savannah Sparrow
Chen c. caerulescens

Grus canadensis canadensis Calidris bairdii

Calidris subruficollis

Calidris melanotos

Calidris pusilla

Calidris mauri

Limnodromus scolopaceus

Catharus minimus aliciae

Passerculus sandwichensis sandwichensis

\section{Asian birds in North America}

\begin{tabular}{ll} 
Lesser Sand-Plover & $\begin{array}{c}\text { Charadrius mongolus } \\
\text { stegmanni }\end{array}$ \\
Wood Sandpiper & Tringa glareola \\
Bar-tailed Godwit & Limosa lapponica ssp. \\
Ruff & Calidris pugnax \\
Curlew Sandpiper & Calidris ferruginea \\
Sky Lark & Alauda arvensis pekinensis \\
Arctic Warbler & Phylloscopus borealis \\
Lanceolated Warbler & Locustella lanceolata \\
Bluethroat & Luscinia svecica svecica \\
Northern Wheatear & Oenanthe oenanthe oenanthe \\
Eastern Yellow Wagtail & Motacilla tschutschensis \\
& tschutschensis \\
White Wagtail & Motacilla alba ocularis \\
Olive-backed Pipit & Anthus hodgsoni yunnanensis \\
Red-throated Pipit & Anthus cervinus \\
Brambling & Fringilla montifringilla \\
\hline
\end{tabular}

those that are probably time-limited at their range edges, to substantially expand their ranges in this region, on a primarily east-west axis. While other factors will affect birds' range shifts in Beringia, we highlight the taxa we consider most likely to respond to longer growing seasons and a corresponding relaxation of time constraints.

\section{ACKNOWLEDGMENTS}

We thank Colleen M. Handel, Steven C. Heinl, and the editors for helpful comments on an earlier draft. We also thank the Cornell Laboratory of Ornithology for permission to reproduce Figure 2.

\section{Literature Cited}

American Ornithologists' Union (AOU). 1957. Checklist of North American Birds, 5th ed. Am. Ornithol. Union, Port City Press, Baltimore.

AOU. 1998. Check-list of North American Birds, 7th ed. Am. Ornithol. Union, Washington, DC.

Angert, A. L., Crozier, L. G., Rissler, L. J., Gilman, S.
E., Tewksbury, J. J., and Chunco, A. J. 2011. Do species' traits predict recent shifts at expanding range edges? Ecol. Lett. 14:677-689; doi 10.1111/j.14610248.2011.01620.x.

Arkhipov, V. Yu, and Ławicki, Ł. 2016. Nearctic passerines in Russia. Dutch Birding 38:201-214.

Auer, S. K., and King, D. I. 2014. Ecological and lifehistory traits explain recent boundary shifts in elevation and latitude of western North American songbirds. Global Ecol. Biogeogr. 23:867-875; doi 10.1111/geb.12174.

Barbet-Massin, M., Thuiller, W., and Jiguet, F. 2012. The fate of European breeding birds under climate, land-use and dispersal scenarios. Global Change Biol. 18:881-890; doi 10.1111/j.13652486.2011.02552.x.

Benson, A. M., Pogson, T. H., and Doyle, T. J. 2000. Updated geographic distribution of eight passerine species in central Alaska. W. Birds 31:100-105.

Benson, A. M., and Winker, K. 2001. Timing of breeding range occupancy among high-latitude passerine migrants. Auk 118:513-519; doi 10.1642/00048038(2001)118 [0513:TOBROA]2.0.CO;2.

Benson, A. M., and Winker, K. 2015. High-latitude passerine migrants overlap energetically demanding events in autumn. Wilson J. Ornithol. 127:601614; doi 10.1676/14-034.1.

Brazil, M. 2009. Birds of East Asia. Princeton Univ. Press, Princeton, NJ.

Browning, M. R. 1988. A new subspecies of Carpodacus roseus. Bull. Br. Ornithol. Club 108:177-179.

Cannell, P. F., Cherry, J. D., and Parkes, K. C. 1983. Variation and migration overlap in flight feather molt of the Rose-breasted Grosbeak. Wilson Bull. 95:621-627.

Chapin, F. S., III, Trainor, S. F., Cochran, P., Huntington, H., Markon, C., McCammon, M., McGuire, A. D., and Serreze, M. 2014. Climate Change Impacts in the United States: The Third National Climate Assessment (J. M. Melillo, Terese (T.C.) Richmond, and G. W. Yohe, eds.), Alaska: chap. 22, pp. 514-536. U.S. Global Change Research Program, Washington, DC; doi 10.7930/J00Z7150.

DeCicco, L. H., and Hajdukovich, N. [R.]. 2008. First record of the Cassin's Vireo nesting in Alaska. W. Birds 39:36-38.

Del Hoyo, J., Elliott, A., Sargatal, J., and Christie, D. 1992-2011. Handbook of the Birds of the World, Vols. 1-16. Lynx Edicions and BirdLife Int., Barcelona.

Erwin, C. A., Rozell, K. B., and DeCicco, L. H. 2004. Update on the status and distribution of Wilson's Phalarope and Yellow-bellied Sapsucker in Alaska. W. Birds 35:42-44.

Flockhart, D. T. T. 2010. Timing of events on the breeding grounds for five species of sympatric warblers. J. Field Ornithol. 81:373-382; doi 10.1111/j.15579263.2010.00293.x.

Gibson, D. D., and Withrow, J. J. 2015. Inventory of the species and subspecies of Alaska birds. W. Birds 46:94-185. 
Gillings, S., Balmer, D. E., and Fuller, R. J. 2015. Directionality of recent bird distribution shifts and climate change in Great Britain. Global Change Biol. 21:2155-2168; doi 10.1111/gcb.12823.

Huntley, B., Collingham, Y. C., Willis, S. G., and Green, R. E. 2008. Potential impacts of climatic change on European breeding birds. PLoS One 3(1): e1439; doi 10.1371/journal.pone.0001439.

Hussell, D. J. T., Bairlein, F., and Dunn, E. H. 2014. Double brooding by the Northern Wheatear on Baffin Island. Arctic 67:167-172.

Kessel, B. 1963. West-east relationships of the birds of northern Alaska, in Pacific Basin Biogeography (J. L. Gressitt, ed.), pp. 79-84. Bishop Museum Press, Honolulu.

Lee, D-H., Torchetti, M. K., Winker, K., Ip, H., Song, C-S., and Swayne, D. E. 2015. Intercontinental spread of Asian-origin $\mathrm{H} 5 \mathrm{~N} 8$ to North America through Beringia by migratory birds. J. Virol. 89:6521-6524; doi 10.1128/JVI.00728-1.5.

MacArthur, R. H., and Wilson, E. O. 1967. The Theory of Island Biogeography. Princeton Univ. Press, Princeton, NJ.

Martin, P. R., Bonier, F., and Gibson, D. D. 2006. First nest of the Yellow-bellied Flycatcher for Alaska, with notes on breeding biology. W. Birds 37:8-22.

Mayr, E. 1946. History of the North American bird fauna. Wilson Bull. 58:3-41.

Mizel, J. D., Schmidt, J. H., Mcintyre, C. L., and Roland, C. A. 2016. Rapidly shifting elevational distributions of passerine species parallel vegetation change in the subarctic. Ecosphere 7(3): e01264; doi 10.1002/ecs2.1264.

National Geographic. 2002. Field Guide to the Birds of North America, 4th ed. Natl. Geogr. Soc., Washington, DC.

Payne, R. B. 1972. Mechanisms and control of molt. Avian Biol. 2:103-105.

Pearce, J. M., Reeves, A. B., Ramey, A. M., Hupp, J. W., Ip, H. S., Bertram, M., Petrula, M. J., Scotton, B. D., et al. 2011. Interspecific exchange of avian influenza virus genes in Alaska: The influence of trans-hemispheric migratory tendency and breeding ground sympatry. Mol. Ecol. 20:1015-1025; doi 10.1111/j.1365-294X.2010.04908.x.

Rimmer, C. C. 1988. Timing of the definitive prebasic molt in Yellow Warblers at James Bay, Ontario. Condor 90:141-146.

Rodewald, P. (ed.). 2015. The Birds of North America Online. Cornell Lab. Ornithol., Ithaca, NY; birdsna.org.
Rowe L., Ludwig, D., and Schluter, D. 1994. Time, condition and the seasonal decline of avian clutch size. Am. Nat. 143:698-722; doi 10.1086/285627.

Runstadler, J., Hill, N., Hussein, I. T. M., Puryear, W., and Keogh, M. 2013. Connecting the study of wild influenza with the potential for pandemic disease. Infect. Genet. Evol. 17:162-187; doi 10.1016/j. meegid.2013.02.020.

Sinclair, P. H., Nixon, W. A., Eckert, C. D., and Hughes, N. L. (eds.). 2003. Birds of the Yukon Territory. Univ. of British Columbia Press, Vancouver.

Stegmann, B. 1963. The problem of the Beringian continental land connection in the light of ornithogeography, in Pacific Basin Biogeography (J. L. Gressitt, ed.), pp. 65-78. Bishop Museum Press, Honolulu.

Tingley, M. P., and Huybers, P. 2013. Recent temperature extremes at high northern latitudes unprecedented in the last 600 years. Nature 496:201-205; doi 10.1038/nature11969.

Tingley, M. W., Koo, M. S., Moritz, C., Rush, A. C., and Beissinger, S. R. 2012. The push and pull of climate change causes heterogeneous shifts in avian elevational ranges. Global Change Biol. 18:32793290; doi 10.1111/j.1365-2486.2012.02784.x.

Tobish, T. [G. Jr.]. 2014. Alaska region (summer 2013). N. Am. Birds 67:638-641.

Vega-Rivera, J. H., McShea, W. J., Rappole, J. H., and Haas, C. A. 1998. Pattern and chronology of prebasic molt for the Wood Thrush and its relation to reproduction and migration departure. Wilson Bull. 110:384-392.

Virkkala, R., and Lehikoinen, A. 2014. Patterns of climate-induced density shifts of species: Poleward shifts faster in northern boreal birds than in southern birds. Global Change Biol. 20:2995-3003; doi 10.1111/gcb.12573.

West, F. H. (ed.). 1998. American Beginnings: The Prehistory and Palaeoecology of Beringia. Univ. of Chicago Press, Chicago.

Winker, K., McCracken, K. G., Gibson, D. D., Pruett, C. L., Meier, R., Huettmann, F., Wege, M., Kulikova, I. V., et al. 2007. Movements of birds and avian influenza from Asia into Alaska. Emerging Infect. Dis. 13:547-552.

Zuckerberg, B., Woods, A. M., and Porter, W. F. 2009. Poleward shifts in breeding bird distributions in New York state. Global Change Biol. 15:1866-1883; doi 10.1111/j.1365-2486.2009.01878.x. 